\title{
PELAKSANAAN PERLINDUNGAN HUKUM MEREK UNTUK PENGUSAHA UKM BATIK DI PEKALONGAN, SOLO, DAN YOGYAKARTA
}

\author{
Agus Sardjono, Brian Amy Prastyo, dan Desrezka Gunti Larasati ${ }^{1}$
}

\begin{abstract}
Batik is one of the traditional cultural expressions Indonesia whose existence has been recognized internationally. Among the various measures of protection of batik, the study was specifically conducted to examine the implementation of legal protection for UKM brands in Pekalongan batik, Solo and Yogyakarta. These three areas were chosen not only for UNESCO recognition that each is the center of batik industry, but also in view of the large number of batik artisans and showroom owners in the three regions. In relation to the legal protection of brands, this study highlights the reality of the utilization of brands by UKM batik, law enforcement activities by the police, and the role of local government. As this study combines quantitative and qualitative methodsempirical, where the data collection is done through the study of documents, interviews, and questionnaires with visits to centers of batik in the three regions.
\end{abstract}

Keywords: batik, UKM, legal protection

\begin{abstract}
Abstrak
Batik merupakan salah satu ekspresi budaya tradisional Indonesia yang eksistensinya sudah diakui secara internasional. Di antara berbagai langkah perlindungan terhadap batik, penelitian ini secara khusus dilakukan untuk mengetahui pelaksanaan dari perlindungan hukum Merek bagi para pengusaha UKM batik di Pekalongan, Solo, dan Yogyakarta. Ketiga daerah tersebut dipilih bukan hanya karena pengakuan UNESCO bahwa masingmasing merupakan sentra industri batik, tetapi juga mengingat banyaknya jumlah pengrajin maupun pemilik showroom batik di ketiga daerah tersebut. Dalam kaitannya dengan perlindungan hukum Merek, penelitian ini menyoroti realitas kegiatan pemanfaatan Merek oleh para pengusaha UKM batik, kegiatan penegakkan hukum oleh aparat kepolisian, dan peran pemerintah setempat. Adapun penelitian ini menggabungkan metode kuantitatif dan kualitatif-empiris, dimana pengumpulan data dilakukan melalui studi dokumen, wawancara, serta penyebaran kuesioner dengan kunjungan langsung ke sentra-sentra batik di ketiga daerah tersebut.
\end{abstract}

Kata kunci: batik, UKM, perlindungan hukum

\footnotetext{
${ }^{1}$ Peneliti pada Pusat Kajian Hak atas Kekayaan Intelektual (HKI) Fakultas Hukum Universitas Indonesia. Alamat kontak: brian@masber.com
} 


\section{Pendahuluan}

Menurut pandangan World Intellectual Property Rights (WIPO), Usaha Kecil dan Menengah (UKM) memiliki banyak potensi untuk tumbuh kembang inovasi dan kreativitas atas produk. Namun, sayangnya kesadaran pengusaha UKM akan pentingnya pemanfaatan Hak Kekayaan Intelektual untuk mendukung kegiatan usaha mereka masih rendah. Sebagai contoh, melalui pemanfaatan Merek sebagai penanda produk, pengusaha UKM dapat membantu konsumen mengenali produk hasil kreasi mereka, sehingga memudahkan para konsumen untuk mencari dan membeli produk-produk tersebut. Dalam kaitannya dengan produk batik, para pengrajin atau pengusaha UKM batik dapat memanfaatkan hak Merek untuk menandai produk batik mereka yang memiliki kekhasan dan karakteristik tersendiri. Dalam hal ini, ragam dan variasi nilai ekspresi tradisional batik yang diproduksi oleh para pengusaha UKM batik tersebut dapat diidentifikasi melalui penggunaan Merek oleh masing-masing pengusaha. Pemanfaatan hak Merek untuk identifikasi produk batik dari pengrajin domestik ini juga dapat menjadi salah satu solusi untuk meningkatkan daya saing pengusaha UKM batik lokal dari ancaman arus perdagangan global.

Salah satu fenomena perdagangan global tersebut adalah derasnya impor batik yang terjadi semenjak tahun 2012 lalu. Arus impor batik tersebut dikatakan meresahkan para pengusaha batik domestik. ${ }^{2}$ Batik impor yang sebenarnya bukanlah batik, melainkan 'tekstil impor dengan motif batik ${ }^{3}$ tersebut diantaranya berasal dari Cina dan Malaysia. Berdasarkan data dari Badan Pusat Statistik (BPS), pada tahun 2012 tercatat sebanyak 1.037 ton (atau setara dengan sekitar Rp 285 miliar) produk tekstil batik Cina yang masuk ke Indonesia ${ }^{4}$. Aneka tekstil batik impor tersebut dipasarkan dengan harga yang

${ }^{2}$ Untuk meningkatkan daya saing pengusaha UKM batik lokal, langkah antisipatif yang diajukan diantaranya adalah dengan membatasi impor tekstil batik melalui peningkatan bea masuk tektil batik impor ke Indonesia. Namun, mengingat komitmen Indonesia untuk ikut serta dalam arena perdagangan bebas, derasnya arus impor akan sulit untuk dikendalikan. Ketua Umum Kamar Dagang dan Industri (Kadin) Indonesia, Suryo Bambang Sulisto, mengatakan solusi yang dapat diambil pemerintah dalam hal ini adalah dengan pemberian insentif sehingga dapat menguatkan industri dalam negeri, termasuk para pengusaha UKM batik tersebut (Riza Khairi, Batik China dan Bawang Putih Impor Banjiri Indonesia, Ini Tanggapan Bos Kadin (11 Maret 2013), http://suarapengusaha.com/2013/02/27/batik-chinadan-bawang-putih-impor-banjiri-indonesia-ini-tanggapan-bos-kadin/).

${ }^{3}$ Zulfi Suhendra, RI Digempur Batik China Sejak 4 Tahun Lalu, Detikfinance (20 Februari 2013), http://finance.detik.com/read/2013/02/20/133528/2175015/4/ridigempur-batik-china-sejak-4-tahun-lalu. Dikatakan oleh Menteri Perencanaan Pembangunan Nasional/Kepala Bappennas, Armida Alisjahbana, batik-batik impor yang masuk ke Indonesia itu bukanlah batik yang sebenarnya karena hanya merupakan tekstil yang dicetak dengan motif batik dan tidak dibuat dengan teknik serta proses tradisional pembuatan batik; Rista Rama Dhany, Tanggapi Serbuan Batik Impor, Menteri Bappenas: Itu Bukan Batik!, Detikfinance (20 Februari http://finance.detik.com/read/2013/02/20/115057/2174877/4/tanggapi-serbuan-batik-impormenteri-bappenas-itu-bukan-batik.

${ }_{4}$ Impor Batik dari China Mencapai Rp 285 Miliar, The Indonesian Way, http://www.theindonesianway.com/impor-batik-dari-china-mencapai-rp-285-miliar/. 
murah, sehingga keberadaannya dapat menyaingi produk-produk batik asli hasil karya pengrajin domestik, yang kebanyakan skala usahanya masih berupa UKM. Konsumen yang kurang memahami perbedaan antara batik lokal dengan tekstil batik impor seringkali menganggap bahwa keduanya merupakan produk batik. Padahal yang dianggap sebagai batik adalah kain dengan motif-motif dan pewarnaan yang dibuat dengan teknik membatik khas tradisional Indonesia, sementara batik impor tersebut hanyalah tekstil yang dicetak (print) dengan motif-motif batik. Hal ini dapat berdampak kerugian bagi pengrajin batik domestik ketika konsumen lebih memilih tekstil batik impor karena harganya yang lebih murah.

Salah satu upaya yang dianggap dapat melindungi nilai ekspresi batik serta meningkatkan daya saing pengusaha UKM batik lokal adalah program Batikmark. Kementerian Perindustrian dan Perdagangan Republik Indonesia meluncurkan program Batikmark yang berfungsi sebagai sertifikasi atas produk batik tulis dan batik cap, yang ditandai dengan penggunaan logo Batikmark 'Batik Indonesia.' Sertifikasi tersebut adalah untuk menjamin bahwa produk batik tulis dan batik cap tersebut diproduksi dengan menggunakan canting tulis atau canting cap dengan peneraan malam, sebagaimana teknik membatik tradisional. Namun, Batikmark ini tidak dimaksudkan sebagai suatu Merek atau penanda produk masing-masing pengusaha UKM batik, meskipun memiliki fungsi sebagai tanda bahwa produk batik tersebut adalah asli Indonesia. ${ }^{5}$ Dalam hal ini Batikmark dapat membantu identifikasi dan sertifikasi terhadap produk batik lokal, namun tidak dapat menunjukkan pengrajin asal dari suatu produk batik. Ditambah lagi, untuk dapat memperoleh sertifikasi tersebut, diperlukan suatu prosedur pendaftaran dan pengujian produk, sehingga mungkin saja pengusaha UKM batik tidak memperoleh sertifikasi karena tidak memenuhi standar tertentu, meskipun batiknya diproduksi dengan teknik membatik tradisional. Oleh karena itu, pelaksanaan program Batikmark ini perlu dikaji lebih lanjut.

Pemanfaatan Merek sebagai identitas dan penanda produk batik lokal dianggap dapat menjadi salah satu solusi, tidak hanya untuk membantu para konsumen dalam membedakan produk batik lokal dengan tekstil batik impor, melainkan juga untuk mengenali pengrajin asal dari produk batik tersebut, yang dengan karakteristik dan kekhasan produknya masing-masing, dapat dibedakan dari produk batik lokal lainnya. Oleh karena itu, penelitian ini mengkaji secara nyata efektivitas pemanfaatan Merek oleh pengusaha UKM batik untuk menandai produk batiknya masing-masing, termasuk pentingnya pemanfaatan Merek tersebut bagi mereka dalam persaingan perdagangan batik. Dari segi perlindungan hukum, penelitian ini mengkaji efektivitas tujuan

\footnotetext{
${ }^{5}$ Rista Rama Dhany, Tanggapi Serbuan Batik Impor, Menteri Bappenas: Itu Bukan Batik!, Detikfinance (20 Februari http://finance.detik.com/read/2013/02/20/115057/2174877/4/tanggapi-serbuanbatik-impor-menteri-bappenas-itu-bukan-batik dan Batik China dan Jiran Ganggu Daya Saing Produk (3 Lokal Agustus 2011), http://ekbis.rmol.co/read/2011/08/03/35131/Batik-China-\&-Jiran-Ganggu-Daya-Saing-ProdukLokal-.
} 
hukum Merek untuk menciptakan persaingan usaha yang sehat, keinginan para pengusaha UKM batik untuk mendaftar hak Merek, bentuk kegiatan penegakan hak Merek oleh aparat kepolisian, serta bentuk dan peran nyata pemerintah setempat agar para pengusaha UKM batik pemegang hak Merek dapat melaksanakan hak-haknya secara efektif. Dari enam kota yang menurut UNESCO merupakan sentra pengrajin batik di Indonesia yaitu DKI Jakarta, Cirebon, Madura, Pekalongan, Solo, dan Yogyakarta $^{6}$, penelitian ini memfokuskan pada pengusaha UKM batik di tiga daerah, yakni Pekalongan, Yogyakarta, dan Solo.

Selain daripada itu, penelitian yang telah ada sebelumnya (prior art research) menunjukkan bahwa karakteristik dari masyarakat pengusaha UKM di beberapa daerah di Pulau Jawa adalah bersifat komunal. Karakteristik komunal ini membuka suatu alternatif baru untuk sistem perlindungan hukum Merek Kolektif, yakni penggunaan Merek bersama oleh pengrajin atau pengusaha UKM batik dari suatu daerah atau kampung tertentu, dimana diantara para pengrajin yang berasal dari suatu komunitas atau sentra/kampung tersebut, dapat diidentifikasi kekhasan yang membedakan mereka dari komunitas atau sentra/kampung pengrajin batik di daerah lainnya. Peluang dan potensi untuk pemanfaatan Merek Kolektif oleh para pengusaha UKM batik dari sentra/kampung tertentu juga menjadi salah satu objek dari penelitian ini.

Berdasarkan latar belakang tersebut, pokok permasalahan yang akan dielaborasi melalui penelitian ini adalah:

1. Bagaimanakah efektivitas pemanfaatan hukum Merek oleh pengusaha UKM batik di Pekalongan, Solo, dan Yogyakarta?

2. Apakah peranan yang dapat dilakukan oleh pemerintah daerah agar pengusaha UKM batik di Pekalongan, Solo, dan Yogyakarta berkeinginan untuk memanfaatkan perlindungan hukum Merek?, dan

3. Bagaimanakah strategi dan bentuk empirik dari pelaksanaan strategi tersebut, dalam upaya meningkatkan pemanfaatan hukum Merek oleh pengusaha UKM batik di Pekalongan, Solo, dan Yogyakarta?

Kegiatan penelitian mencakup studi dokumen mengenai hukum Merek dan industri batik di Pekalongan, Solo, dan Yogyakarta, dilanjutkan dengan kunjungan lapangan ketiga daerah tersebut untuk memperoleh data secara empiris. Analisis data akan dilakukan secara kuantitatif dan kualitatif-empiris. Untuk memperoleh data empiris mengenai efektivitas pemanfaatan Merek dan pentingnya perlindungan Merek bagi para pengusaha UKM batik, peneliti akan mengumpulkan data melalui penyebaran kuesioner dan wawancara dengan para pengusaha UKM batik di ketiga daerah tersebut. Wawancara juga dilakukan terhadap anggota forum atau paguyuban dari sentra atau kampung tempat para pengusaha UKM batik tersebut berasal. Untuk mengetahui jumlah

${ }^{6}$ UNESCO (United Nations Educational, Scientific and Cultural Organizations), Indonesian Batik, http://www.unesco.org/culture/ich/RL/00170; dan Nomination for Inscription on the Representative List in 2009 (Reference No. 00170), State Party: Indonesia, Name of Element: Indonesian Batik, Intergovernmental Committee for the Safeguarding of the Intangible Cultural Heritage. 
populasi pengusaha UKM batik di ketiga daerah tersebut, peneliti akan meminta data dari Dinas Perindustrian dan Perdagangan setempat, serta dari forum atau paguyuban pengusaha UKM batik. Teknik pengambilan sampel dilakukan secara non-probability dan purposive dengan mengacu pada table Krecjie-Morgan. Sebelum penyebaran kuesioner kepada sampel pengusaha dilakukan, kuesioner diuji coba terlebih dahulu pada pengusaha UKM batik dari Pekalongan, Solo, dan Yogyakarta yang memiliki kios atau lapak di Thamrin City, Jakarta. Setelah data diperoleh melalui kuesioner dan wawancara, kegiatan focus group discussion (FGD) dilaksanakan dengan mengundang para pihak dari instansi pemerintah terkait, pemerintah setempat, serta perwakilan dari para pengusaha UKM batik di ketiga daerah tersebut. FGD ini dimaksudkan untuk mengkaji mengenai peranan yang dapat dilakukan oleh pemerintah daerah, serta strategi dan bentuk empirik dari pelaksanaan strategi tersebut agar pengusaha UKM batik di Pekalongan, Solo, dan Yogyakarta dapat memanfaatkan Merek dan perlindungan hukum Merek untuk pengembangan industri batiknya.

\section{Pembahasan}

\section{Aspek Hukum Merek}

Black's Law Dictionary mendefiniskan Merek sebagai "A word, phrase, logo or other graphic symbol used by a manufacturer or seller to distinguish its product from those of others". Sementara, menurut World Intellectual Property Organization (WIPO) Intellectual Property Handbook, Merek diartikan sebagai “... any sign that individualizes the goods of a given enterprise and distinguishes them from the goods of its competitors". Dalam definisi WIPO tersebut dikemukakan bahwa Merek harus memiliki daya pembeda (it must be distinctive) dan tidak boleh memiliki potensi untuk mengelabui (it should not be deceptive). Sementara, dalam the Agreement on Trade Related Aspects of Intellectual Property Rights (TRIPs), Merek diatur dalam Article 15.1 yang menyebutkan bahwa "Merek dagang adalah setiap tanda atau kombinasi dari tanda yang mampu membedakan barang atau jasa dari satu badan ke badan usaha lain. Tanda tersebut meliputi kata, termasuk nama perorangan, surat, angka, unsur-unsur figuratif dan kombinasi warna, juga kombinasi tanda". ${ }^{7}$ Menurut Undang-Undang Nomor 15 Tahun 2001 tentang Merek ("UU Merek"), Merek adalah tanda yang berupa gambar, nama, kata, huruf-huruf, angka-angka, susunan warna, atau kombinasi dari unsur-unsur tersebut yang memiliki daya pembeda

\footnotetext{
${ }^{7}$ Pasal 15 TRIPs: Any sign, or any combination of sign, capable of distinguishing the goods or services of one undertaking from those of undertaking, shall be capable of constituting a trade mark. Such signs, in particular words, including personal names, letters, numerals, figurative elements and combinations of colours as well any combination of such signs, shall be eligible for registration as trademarks.
} 
dan digunakan dalam kegiatan perdagangan atau jasa. Dalam hal ini, Merek dapat dibedakan menjadi dua jenis, yakni Merek Dagang yang digunakan pada barang yang diperdagangkan, dan Merek Jasa yang digunakan pada jasa yang diperdagangkan.

Dari sudut pandang konsumen, Merek dapat menjadi penanda dari suatu produk yang menunjukkan asal produsennya, sehingga ia dapat memilih produk tertentu dari produsen tertentu tersebut, diantara produkproduk lainnya yang sejenis. Pemilihan produk berdasarkan Merek tersebut dapat dilakukan oleh karena keberhasilan pemasaran produk, reputasi yang dimiliki oleh si produsen (good will), ${ }^{8}$ jaminan kualitas atas produk, atau bahkan atas dasar pertimbangan bahwa produk tersebut memenuhi selera konsumen. Sehingga, terkadang dapat melekat image tertentu di mata konsumen terhadap suatu Merek atas produk tertentu? Image tersebut berkaitan dengan reputasi dari produk atau produsennya, dan konsumen dapat menjadi loyal untuk terus membeli atau menggunakan produk dengan Merek tersebut karena reputasi atau image yang terbangun.

Sementara, berkaitan dengan Merek Kolektif, UU Merek menyebutkan bahwa Merek Kolektif merupakan Merek yang digunakan pada barang dan/atau jasa dengan karakteristik yang sama yang diperdagangkan oleh beberapa orang atau badan hukum secara bersanasama untuk membedakan dengan barang dan/atau jasa sejenis lainnya. Klasifikasi Merek Kolektif tidak membuat adanya tiga jenis merek. Jenis Merek tetap hanya dua yaitu Merek Dagang dan Merek Jasa. Perbedaan pada Merek Kolektif terletak pada subyek pemakai merek, yaitu boleh secara kolektif, sementara Merek Dagang atau Jasa biasanya digunakan oleh perorangan. Merek Kolektif boleh digunakan oleh beberapa orang (gabungan orang) atau boleh juga badan hukum (gabungan korporasi).

Menurut WIPO IP Handbook, Merek Kolektif biasanya dimiliki oleh sebuah asosiasi atau perusahaan, yang anggotanya dapat menggunakan Merek Kolektif tersebut untuk memasarkan produk-produk yang mereka miliki. Biasanya asosiasi tersebut menetapkan serangkaian kriteria bagi pengusaha yang ingin menggunakan Merek Kolektif tersebut (misalnya standar kualitas), yang memungkinkan bagi pengusaha secara individu untuk memenuhinya. Merek Kolektif merupakan cara yang efektif untuk memasarkan secara bersama produk-produk yang dihasilkan oleh suatu kelompok pengusaha yang mungkin merasa kesulitan untuk mendapatkan

\footnotetext{
${ }^{8}$ Hal senada dinyatakan oleh Arthur R. Miller dan Michael H. Davis: "The trademark function not to distinguish on the basis of origin but on the basis of the atributing to the product qualities of consumer preference based on advertising, its value to the owner is essentially good will." (Arthur R Miller, Michael Davis, Intellectual Property, Patent, Trademarks and Copyright (UK: West Publishing Co, 1990), hal. 131).

9 Ihsan Budi Maulana, Ridwan Khairandy dan Nurjihad, Kapita Selekta Hak Kekayaan Intelektual I (Yogyakarta: Pusat Studi Hukum UII, 2000), hal. 114-115.
} 
pengakuan konsumen dan/atau kepercayaan para penyalur utama atas produknya apabila menggunakan merek sendiri. ${ }^{10}$

Dengan mendaftarkan Merek ke Direktorat Jenderal Hak Kekayaan Intelektual ("DJHKI"), pengusaha dapat memperoleh hak Merek. Hak Merek merupakan hak eksklusif dengan jangka waktu tertentu bagi pemegang hak Merek untuk dapat menggunakan sendiri Merek tersebut atau memberi izin kepada pihak lain untuk menggunakannya. UU Merek menganut sistem konstitutif, dimana perlindungan hak Merek diberikan kepada pihak yang pertama kali mendaftarkan. Dalam hal ini, hak eksklusif atas penggunaan Merek diberikan karena adanya pendaftaran (required by registration). UU Merek mengatur bahwa pendaftaran tersebut pun harus berdasarkan suatu itikad baik. Pengaturan ini dimaksudkan untuk melindungi pemilik Merek yang tidak terdaftar, apabila ada pihak lain yang mendaftar Merek yang mirip atau sama dengan Merek si pemilik pertama tersebut. Berdasarkan ketentuan UU Merek, pendaftaran dapat memberikan hak ekslusif kepada pemilik merek guna mencegah pihak-pihak lain untuk memasarkan produkproduk yang identik atau mirip dengan produk dari pengusaha yang bersangkutan dengan menggunakan Merek yang sama dengan pengusaha, atau yang dapat membingungkan konsumen karena suatu kemiripan atau kesamaan pada Merek tersebut.

Permohonan pendaftaran Merek Kolektif pada umumnya sama dengan pendaftaran Merek biasa. Hanya saja dalam permohonan pendaftaran Merek Kolektif, harus ada pernyataan yang berisi penegasan bahwa Merek tersebut akan digunakan sebagai Merek Kolektif. Disamping itu, permohonan pendaftaran juga wajib menyertakan salinan peraturan penggunaan Merek sebagai Merek Kolektif yang ditandatangani oleh semua pemilik merek yang bersangkutan. ${ }^{11}$ Hal demikian diatur dalam Pasal 50 ayat (2) UU Merek 2001, yang berbunyi:

\section{Selain penegasan mengenai penggunaan Merek Kolektif sebagaimana dimaksud pada ayat (1) Permohonan tersebut wajib disertai salinan ketentuan penggunaan Merek tersebut sebagai Merek Kolektif, yang ditandatangani oleh semua pemilik Merek yang bersangkutan”. Syarat ini merupakan}

10 "Intellectual Property for Business Series Number 1: Membuat Sebuah Merek", http://www.wipo.int/export/sites/www/sme/en/documents/guides/translation/m aking_a_mark_indo.pdf, 4 Juli 2013.

${ }^{11}$ WIPO menyebut peraturan penggunaan Merek Kolektif sebagai "The Regulation Concerning the Use of Collective Mark". Peraturan penggunaan merek kolektif tersebut berlaku bagi setiap pihak yang ikut menggunakan Merek Kolektif yang bersangkutan. Hal itu bertujuan agar kualitas dan reputasi dari produk barang dan/atau jasa yang ditawarkan Merek bersangkutan dapat terus terjaga. Peraturan penggunaan merek kolektif harus memuat: (a) sifat, ciri-ciri umum atau mutu dari barang atau jasa yang akan diproduksi dan diperdagangkan; (b) pengaturan bagi pemilik Merek Kolektif untuk melakukan pengawasan yang efektif atas penggunaan Merek tersebut; dan (c) Sanksi atas pelanggaran peraturan penggunaan Merek Kolektif (Indonesia (1), Undang-Undang tentang Merek, UU Nomor 15 Tahun 2001, LN No. 110 Tahun 2001, TLN No. 4131, Pasal 50 ayat (3). 
tambahan pada persyaratan permintaan pendaftaran Merek biasa.

Seperti halnya mengenai persyaratan, tata cara pengajuan permohonan pendaftaran, pemeriksaan kelengkapan dan pemeriksaan substantif serta pendaftaran Merek Kolektif, tuntuk sepenuhnya kepada ketentuan pendaftaran Merek biasa. Apabila Pemeriksa Merek berkesimpulan permohonan pendaftaran sebagai Merek Kolektif dapat disetujui, maka Kantor Merek akan mecatat Merek tersebut dalam Daftar Umum Merek dengan melampirkan salinan peraturan penggunaan Merek Kolektif. Kemudian, pendaftaran Merek Kolektif berikut salinan peraturan penggunaannya akan diumumkan dalam Berita Resmi Merek. Perbedaan pencatatan pendaftaran dalam Daftar Umum Merek maupun pengumuman dalam Berita Resmi Merek antara Merek biasa dengan Merek Kolektif hanya terletak pada "lampiran". Pada Merek Kolektif, pencatatan pendaftaran dan pengumuman harus ikut melampirkan salinan ketentuan peraturan penggunaan Merek Kolektif. Masa perlindungan hukum atau jangka waktu bagi perlindungan hak Merek biasa maupun hak Merek Kolektif adalah sama, yakni selama 10 tahun, dan dapat diperpanjang. Kemudian, dalam sertifikat Merek Kolektif, kode nomor agenda dan nomor sertifikat pada pokoknya sama dengan Merek biasa. Hanya saja, dalam kolom nama pemilik terdaftar dituliskan semua pemilik dari Merek Kolektif yang tercantum dalam permohonan pendaftaran Merek.

Pada dasarnya Merek biasa maupun Merek Kolektif tidak wajib didaftarkan. Meski demikian, apabila pemilik Merek ingin mendapat perlindungan akan "tanda" yang digunakan dalam kegiatan perdagangannya, maka tanda sebagai Merek tersebut harus didaftarkan. Sebagaimana dikatakan sebelumnya, Merek yang terdaftar memperoleh hak esklusif untuk mencegah penggunaan Merek oleh pihak lain yang tidak berwenang. ${ }^{12}$ Sesuai dengan ketentuan bahwa hak Merek itu diberikan pengakuannya oleh negara, maka pendaftaran atas Mereknya merupakan suatu keharusan apabila ia menghendaki agar menurut hukum dipandang sah sebagai pihak yang berhak atas Merek. Pendaftaran Merek akan memberikan perlindungan yang lebih kuat khususnya jika menghadapi Merek yang identik atau yang mirip. Bagi pihak yang mendaftarkan Mereknya tersebut, terdapat suatu kepastian hukum bahwa dialah yang berhak atas pemilikan dan penggunaan Merek tersebut. Sebaliknya, bagi pihak lain yang mencoba untuk mendaftar Merek yang sama atau mirip dengan Merek terdaftar untuk barang atau jasa yang sejenis, DJHKI akan menolak pendaftaran tersebut. ${ }^{13}$

12 Wawancara dengan Jujun Jaenuri, Kasie Setifikasi, Perpanjangan, Mutasi dan Lisensi Direktorat Merek Dirjen HKI, Jakarta, 4 Juli 2013.

${ }^{13}$ Drs. Muhammad Djumhana dan R. Djubaedillah, Hak Milik Intelektual: Sejarah, Teori dan Prakteknya di Indonesia (Bandung: Citra Aditya Bakti, 2003), hal. 175. 


\section{Industri Batik di Pekalongan, Solo, dan Yogyakarta}

Pada tanggal 2 Oktober 2009, UNESCO mengakui Batik dari Indonesia sebagai salah satu warisan budaya dunia. Kata 'batik' awalnya berasal dari bahasa Jawa 'ambatik', yang merupakan gabungan dari dua kata yakni 'amba' yang artinya menulis (atau ada pula yang menerjemahkan sebagai 'kain'), dan 'titik', 14 sehingga batik berarti menulis corak/motif titik-titik atau totol pada selembar kain (dots or spots) sehingga menghasilkan gambar atau motif tertentu. Dari kegiatan 'membatik', dihasilkan batik atau batikan dengan bermacam-macam motif dengan ciri khas tersendiri. Perkembangan seni membatik di Pulau Jawa adalah berkaitan dengan cara membuat kain batik. Sementara mengenai variasi motif-motif batik yang ada adalah perkembangan dari paduan berbagai pengaruh kebudayaan lainnya. ${ }^{15}$ Pada perkembangan awalnya, kain batik dibuat dengan cara menggambarkan motif atau corak titik dan garis pada kain dengan menggunakan lilin (malam) panas dan alat tembaga berujung seperti pensil, yang disebut canting tulis. Penggambaran motif batik dilakukan dengan pemberian malam menggunakan canting secara manual seperti ditulis dengan tangan. ${ }^{16}$ Kain yang telah diberi motif atau corak kemudian dicelup untuk memberikan warna. ${ }^{17}$ Pewarnaan ini menggunakan teknik khusus dengan malam (wax-resist dyeing), dimana bagian kain yang tidak ingin diwarnai ditutup dengan malam. Kain yang sudah dibatik dicelup ke dalam cairan warna secara berulang-ulang untuk memperoleh warna yang diinginkan. Batik yang dibuat dengan canting tulis dan malam tersebut dinamakan 'Batik Tulis.'

Proses pembuatan batik tulis meliputi beberapa tahapan yakni mola (membuat pola), mbathik yang meliputi: ngiseni (mengisi bagian yang sudah dibuat polanya dengan malam menggunakan canting tulis), nerusi (membatik pada sisi sebaliknya), nemboki (menutup bagian kain yang tidak akan diwarnai menggunakan malam), mbriki (proses penghalusan tembokan), medel (pencelupan kain untuk memberikan warna dasar), ngerok atau nggirah (menghilangkan malam pada bagian-bagian kain yang akan diberi warna lain), mbironi (menutup bagian-bagian kain yang akan tetap berwarna dasar), nglorot (merebus kain agar malam larut/lepas), dan mbabari (tahap penyelesaian). ${ }^{18}$

\footnotetext{
${ }^{14}$ Tentang Batik, wwW.museumbatik.com, diakses pada 9 Juli 2013.

${ }^{15}$ Drs. Hamzuri, Batik Klasik (Djambatan, 1989), hlm. VI.

${ }^{16}$ Ari Wulandari, Batik Nusantara: Makna Filosofis, Cara Pembuatan, dan Industri Batik, Edisi 1 (Yogyakarta: ANDI, 2011), hlm 151.

${ }^{17}$ Op.cit. Nomination for Inscription.

18 Dalam prosesnya, mola atau nyorek pada kain batik dilakukan dengan cara menjiplak dari pola motif yang sudah ada, yang biasanya dibuat di atas kertas roti terlebih dahulu. Sementara apabila membatik yang dilakukan tanpa pola disebut ngrujak. Kemudian tahap berikutnya adalah ngisen-isen yakni mengisi pola dengan berbagai macam bentuk. Di dalam proses isen-isen juga terdapat nyecek, yakni membuat isian dalam pola yang sudah dibuat dengan cara memberi titik-titik (nitik). Selanjutnya adalah nerusi, dimana kain yang
} 
Kualitas dari pewarnaan batik yang dihasilkan dari celupan dapat terlihat dari meresapnya bahan pewarna pada kain, seberapa cepat warna tersebut menyebar, dan apakah pewarnaan tersebut mudah pudar. Dikatakan bahwa resep bahan pewarnaan dalam pembuatan batik diwariskan secara turun-temurun oleh para pengrajin dari generasi ke generasi. Empat macam pewarnaan yang terkenal untuk batik dari Jawa adalah: indigo (tom) dari tumbuhan indigo yang menghasilkan warna kebiru-biruan, mengkudu dari tumbuhan morinda citrifolia untuk warna merah, tegerang dari tumbuhan cudriana javanesis untuk warna kuning, dan soga yang merupakan warna cokelat/kuning tua karakteristik batik dari Surakarta dan Yogyakarta, berasal dari akar pohon pelthophorum ferrugineum. ${ }^{19}$ Alat-alat dan bahan yang digunakan dalam pembuatan batik tulis dalam hal ini mencakup: canting tulis, malam, wajan untuk mencairkan malam), gawangan untuk membentangkan kain (mori) sewaktu dibatik, bandul untuk menahan kain yang baru dibatik agar tidak mudah tergeser ditiup angin, anglo sebagai perapian untuk pemanas malam, tepas untuk membesarkan api sesuai kebutuhan yang terbuat dari bambu, taplak untuk mencegah tetesan malam mengenai paha atau kaki si pembatik saat proses membatik, saringan malam untuk menyaring kotoran malam, dingklik untuk tempat duduk si pembatik, mori yakni kain bahan baku batik yang dapat berupa katun (kain juga dapat berupa sutera), serta bahan-bahan pewarna alami. ${ }^{20}$

Dalam perkembangannya, teknologi melahirkan batik jenis baru, yakni 'Batik Cap,' dengan menggunakan stempel/cap tembaga yang disebut sebagai cap, dan 'Batik Cetak' (printing atau sablon), sementara batik tulis dianggap sebagai batik yang dibuat dengan teknik tradisional $^{21}$. Batik cap muncul sekitar tahun 1840-an, dan penggunaannya didominasi oleh pengrajin batik pria, semetara pengrajin wanita mengerjakan batik tulis. Dalam proses pen-cap-an, kain dibentangkan di atas meja datar dan motif-motif dibuat dengan mencelupkan cap ke dalam malam kemudian men-cap-kannya ke atas kain. Kombinasi antara cap dan tulis juga dapat dilakukan pada kain batik. ${ }^{22}$ Perkembangan pembuatan batik dengan menggunakan cap, dan kemudian akhirnya printing atau sablon ini dianggap sebagai suatu

sedang dibatik kemudian dibalik permukaannya, dan dibatik kembali pada permukaan yang kedua itu. Nerusi berfungsi untuk mempertebal tembusan batikan pertama serta untuk memperjelas. Op.cit. Drs. Hamzuri, hlm. 16-17, dan Batik Tulis, http://www.kampoenglaweyan.com, diakses pada 17 Juli 2013.

${ }^{19}$ Inger McCabe Elliot, Batik - Fabled Cloth of Java (Periplus Editions (HK) Ltd., 2004), hlm 56.

${ }^{20}$ DRS Hamzuri, Batik Klasik-Classical Batik, cetakan ke-3 (Jakarta: Djambatan, 1989), 3-12, dan Ari Wulandari, Batik Nusantara: Makna Filosofis, Cara Pembuatan, dan Industri Batik, Edisi 1 (Yogyakarta: ANDI, 2011), 151, dalam Dyan Ratna Sari, Ekses Pasal 10 UU No. 19 Tahun 2002 tentang Hak Cipta Terkait Pemanfaatan Motif Batik Surakarta, Skripsi (Fakultas Hukum Universitas Indonesia, 2013) 37-38.

${ }^{21}$ Op.cit. Tentang Batik.

${ }^{22}$ Op.cit., Inger McCabe Elliot, hlm. 54. 
modernisasi dalam pembuatan batik karena dapat mempercepat proses pengerjaan. Namun, dikatakan oleh Hamzuri, bahwa pembuatan batik dengan cap menghasilkan motif seperti batik yang sebenarnya bukan batik lagi karena mutunya tidak mungkin dapat mengimbangi batik yang sebenarnya, yakni yang dibuat dengan canting tulis (batik tulis). Batik tulis dibuat dengan proses yang panjang dan sangat membutuhkan keahlian dari si pembatik, sehingga harganya cukup mahal jika dibandingkan dengan jenis batik lainnya.

Motif dan corak batik melambangkan nilai-nilai yang hidup di dalam masyarakat, seperti status sosial, komunitas lokal, alam, sejarah, dan warisan budaya. ${ }^{23}$ Simbol-simbol dalam motif batik tidak hanya dibuat berdasarkan kaidah estetika belaka, namun juga bersumber dari harapanharapan yang kemudian dituangkan ke dalam variasi motif dan corak kain batik. Setiap corak batik ini dipercaya sebagai simbol-simbol penuh makna yang memperlihatkan cara berpikir masyarakat pembuatnya. ${ }^{24}$ Setiap variasi corak dan motif kain batik memiliki makna tersendiri dan dibuat untuk dipergunakan dalam peristiwa tertentu, seperti untuk upacara perkawinan, untuk menggendong bayi, upacara mitoni (tujuh bulanan ibu hamil), acara pesta, untuk dipakai sehari-hari, juga untuk digunakan untuk menutup jenazah. Selain itu, Sebagai sandang atau pakaian di masyarakat Jawa, batik digunakan menjadi beberapa jenis kostum yang dikenakan untuk tujuan-tujuan tertentu, yakni: sarong yang dikenakan menutupi pinggang hingga kaki sebagai sarung atau rok; dodot yang biasanya dikenakan sultan, mempelai wanita atau pria, atau para penari kraton; kain panjang atau kain yang digunakan untuk menutupi bagian tubuh dari pinggang hingga pergelangan kaki dan lebih formal daripada sarong; pagi-sore yakni kain yang dapat dibolak-balik dengan dua motif yang terbagi secara diagonal sehingga satu kain dapat menampilkan efek motif yang berbeda; selendang yaitu kain sempit dan panjang yang biasanya digunakan wanita untuk membawa sesuatu atau sebagai syal, termasuk untuk menggendong bayi; iket kepala yang digunakan oleh para pria untuk turban; dan kemben yakni kain yang digunakan untuk menutupi dada/tubuh bagian atas wanita sekaligus juga sebagai pengencang sarong, dan dapat digunakan sebagai pengganti kebaya atau didalam kebaya. $^{25}$

Batik Indonesia dapat dibedakan menjadi beberapa jenis, yaitu: ${ }^{26}$

Batik Kraton Jawa atau Batik Jawa Klasik dan Batik Pesisir. Batik Kraton Jawa merupakan yang tertua di Jawa. Batik ini biasa disebut pula sebagai 'Batik Pedalaman' (inland batik). Batik ini merepresentasikan

\section{${ }^{23}$ Op.Cit. Nomination for Inscription.}

${ }_{24}$ Batik dan Nilai Heritage,

http://www.batikyogyakarta.com/category/sejarah/, diakses pada 9 Juli 2013.

${ }^{25}$ Op.cit. Inger McCabe Elliot, hlm. 33-34.

${ }^{26}$ Evi Steelyana, Batik, A Beautiful Cultural Heritage that Preserve Culture and Support Economic Development in Indonesia (Bina Nusantara University), diakses melalui www.ssrn.com, pada 9 Juli 2013, hlm. 6. 
kualitas artistik dan estetik budaya Jawa. Jenis Batik Kraton pada umumnya menggunakan warna-warna tanah, seperti hitam, cokelat dan kuning tua (soga), yang terkadang dibuat dengan berlatar putih. Batik Pedalaman memiliki gaya dan karakternya tersendiri, yakni teratur, rapi, dan biasanya geometris. Motif Batik Kraton mengandung simbol-simbol tertentu, dan tidak semua orang dapat menggunakan atau memakai batik dengan motif-motif yang ada. Di pulau Jawa, hingga saat ini dua kota dimana dua Kraton Jawa terletak terus melestarikan dan mengembangkan seni dan tradisi batik. Yang pertama adalah kota Surakarta (Solo) (Kasunanan Surakarta), dengan pusat produksi batik di distrik Laweyan dan Kauman, dan pusat perdagangan di Pasar Klewer dan Susuhunan. Batik Solo pada umumnya menggunakan warna dasar soga. Sementara, batik yang berasal dari Yogyakarta (Kasultanan Yogyakarta), umumnya menggunakan warna dasar putih. Beberapa pusat produksi batik diantaranya adalah Imogiri dan Kampung Taman, sementara pusat pedagang ritel berlokasi di pasar Beringharjo dan Mirota, dekat jalan Malioboro. Meski motif-motif yang digunakan berasal dari akar yang sama, para pembatik dari kedua kota menggunakan intensitas pewarnaan yang berbeda untuk menginterpretasikan bentuk dan simbol-simbol motif geometris khas Jawa, sehingga masing-masing memiliki ciri khas tersendiri.

Batik Pesisir diproduksi oleh beberapa wilayah yang terletak di sekitaran pantai utara Jawa, dan Madura. Ramainya perdagangan lewat laut di pantai utara Jawa membuat Batik Pesisir berbeda dengan Batik Kraton (Batik Pedalaman), karena Batik Pesisir banyak mendapat pengaruh dari asing seperti dalam hal desain, pewarnaan, dan motif. Pengaruh tersebut adalah dari Eropa, Cina, dan Arab. Hal yang membuat Batik Pesisir begitu unik adalah karena variasi dalam gaya motif batiknya, dimana banyak digunakan warna cerah dan motif yang beragam. Salah satu contohnya adalah motif dengan pengaruh dari Cina, yakni motif-motif awan, phoenix, naga, bunga teratai, dan pola-pola bunga. Salah satu kota di Jawa Tengah yang terkenal memproduksi Batik Pesisir adalah Pekalongan. Motif-motif Batik Pekalongan dipengaruhi oleh gaya Eropa (Belanda) dan Cina, seperti dalam bentuk motif buket bunga Eropa.

Dapat diketahui bahwa masing-masing daerah atau wilayah memiliki dan memproduksi batik dengan kekhasan tersendiri berdasarkan elemenelemen kebudayaan yang hidup di dalam masyarakatnya. Hal ini lah yang membuat Batik Indonesia begitu beragam dalam variasi motif dan coraknya. Bahkan, dapat pula suatu daerah yang memproduksi batik seperti Yogyakarta, meskipun sama dalam hal karakteristik motif dan corak batiknya, batik yang dihasilkan pengrajin atau produsen yang satu berbeda dalam hal kualitas pewarnaan atau nuansanya dengan batik produksi lain yang serupa. Dalam kegiatan perdagangan, perbedaanperbedaan tersebut tidak hanya menjadi modal pembeda bagi produsen atau pengrajin atas hasil karya batiknya, tetapi juga menjadi penanda 
kualitas dan nilai jual untuk para pelanggan atau konsumennya. Perkembangan teknologi yang mempengaruhi produksi batik, seperti dengan menggunakan mesin cetak (print) atau sablon juga mengundang reaksi dari masyarakat yang menganggap bahwa batik yang tidak dibuat dengan menggunakan canting dan malam (batik tulis) bukanlah merupakan 'batik' melainkan hanya kain atau tekstil bermotif batik. Agaknya komunitas dan masyarakat pecinta batik kemudian menjadi dihadapkan pada beberapa pilihan, yakni secara ideal terus memilih dan menggunakan batik tradisional, seperti batik tulis, atau memilih batik cetak/sablon yang dibuat dengan teknologi modern dan cenderung lebih murah harganya.

Sehubungan dengan pengusaha UKM batik, Teruo Sekimoto (2003: 9) menyebutkan bahwa variasi besar-kecilnya skala usaha dan pengorganisasian pekerjaan pada kerajinan batik mencakup tingkat paling bawah, yakni home industry, dimana satu keluarga mengerjakan semua proses pembuatan batik di rumahnya sendiri tanpa memakai tenaga orang lain. Sementara, di tingkat paling atas terdapat perusahaan batik besar yang memiliki pabrik besar untuk produksi kain (mori), bengkel kerja untuk proses pembatikan, dan juga toko-toko besar untuk langsung menjual produknya kepada konsumen. Pengusaha-pengusaha batik berskala besar biasanya memiliki sistem kontrak usaha dengan pengusaha-pengusaha kecil di sentra-sentra batik seluruh Jawa, sekaligus sebagai perusahaan perdagangan yang membeli batik dari produsenprodusen kecil menengah. Jumlah pekerja per unit usaha tersebut bervariasi dari hanya beberapa orang hingga hampir seratus orang. Dalam hal ini, usaha batik yang dapat dianggap paling representatif sebagai pengrajin batik adalah pengusaha UKM yang memiliki bengkel di belakang rumahnya sendiri, mengerjakan serta mengupahi pekerjapengrajin batik, dan memiliki showroom untuk menjual produksi batiknya tersebut.

\section{a. Sentra Batik di Solo}

Sebagai salah satu wilayah dengan seni Batik Pedalaman yang tertua, kota Solo memiliki 2 (dua) kampung sentra produksi batik, yakni Kauman dan Laweyan. ${ }^{27}$ Seni batik Kauman boleh dikatakan mewarisi langsung inspirasi mbatik Ndalem Kraton Kasunanan Surakarta Hadiningrat. Seni batik Kampung Kauman dapat dibedakan menjadi 3 (tiga) bentuk yakni batik klasik motif pakem (batik tulis), batik murni cap, dan model kombinasi antara batik tulis dan batik cap. Batik tulis bermotif pakem dengan pengaruh seni batik

${ }^{27}$ Target responden dari penelitian ini atas industri batik di kedua kampung tersebut adalah para pengusaha UKM batik. Menurut pemerintah Kota Surakarta, berkaitan dengan skala usaha UKM, kriteria yang menjadi acuan adalah jumlah tenaga kerja. Perusahaan atau usaha dengan tenaga kerja lebih dari 20 (dua puluh) orang dikategorikan sebagai perusahaan sedang dan besar. Ibid. 
Kraton Kasunanan merupakan produk unggulan dari Kampung Kauman dengan bahan dasar kain sutra alam, sutra tenun, katun jenis premisima dan prima, serta rayon. Pengaruh dari Hindu menampilkan ornamen Garuda, Naga, Bunga Teratai, Pohon Hayat dan sebagainya dari motif Batik Kraton. Selain itu, motif juga dipengaruhi agama Islam. Namun, karena Islam melarang bentuk manusia dalam wujud yang sebenarnya, dalam motif batik semua ornamen selalu merupakan bentuk yang distilir atau dalam bentuk lambang, misalnya bunga melambangkan wanita. ${ }^{28}$ Menurut data tahun 2013 dari Paguyuban Kampung Wisata Batik Kauman Surakarta, saat ini terdapat 62 pengusaha UKM batik yang bergerak di berbagai macam bidang seperti sebagai pengrajin, pemilik showroom, produksi kaos batik, konvenksi, dan sablon.

Sebagai salah satu sentra penghasil batik, dalam sejarah Kampung Laweyan dikenal golongan saudagar atau juragan batik dengan pihak wanita sebagai pemegang peranan penting dalam menjalankan roda perdagangan batik, yang biasa disebut sebagai mbok mase atau nyah nganten, sementara sang suami disebut sebagai mas nganten sebagai pelengkap utuhnya keluarga. ${ }^{29}$ Produk batik Kampung Laweyan dibagi menjadi 3 (tiga) jenis, yakni batik tulis, batik cap, dan batik printing atau sablon. Industri batik di Laweyan berkembang pesat setelah lahirnya teknik batik cap. Motif pada batik cap tidak dibuat dengan menggunakan canting, melainkan dengan cap tembaga. Berdasarkan data tahun 2011 yang diperoleh dari Forum Pengembangan Kampung Batik Laweyan (FPKBL), saat ini terdapat 92 pengusaha UKM batik yang bergerak di berbagai macam bidang mencakup: industri batik proses, industri batik konveksi, showroom atau toko, dan industri batik proses atau konveksi sampai dengan showroom.

\section{b. Sentra Batik di Yogyakarta}

Propinsi D.I. Yogyakarta memiliki luas $3.185,80 \mathrm{~km}^{2}$, dan terdiri dari 4 (empat) kabupaten dan 1 (satu) kota, yakni Kota Yogyakarta, Kabupaten Sleman, Kabupaten Bantul, Kabupaten Gunungkidul, dan Kabupaten Kulonprogo. Kota Yogyakarta juga dikenal sebagai kota batik, mengingat sejarah perkembangan batik yang juga hidup dalam Kraton dan masyarakat Yogyakarta semenjak dahulu. Batik menjadi komoditi andalan Yogyakarta, termasuk untuk ekspor. Jenis batik dari Yogyakarta mencakup batik tulis, batik cap, batik cetak (printing), dan juga batik lukis. Yogyakarta memiliki Balai Besar Kerajinan dan Batik yang didirikan pada tahun 1922, awalnya dengan nama Textile Inrichting En Batik Proefstation. Balai ini memiliki visi menjadi pusat penelitian dan pengembangan serta

\footnotetext{
${ }^{28}$ Ibid.

${ }^{29}$ Sosial Budaya - Kampoeng Laweyan, Ibid.
} 
pelayanan jasa teknis industri kerajinan dan batik yang kreatif, inovatif, dan profesional. Termasuk dalam lingkup tugas dan fungsi Balai adalah untuk memberikan sertifikasi Batikmark. ${ }^{30}$ Hingga saat ini, terdapat sekitar 400 (empat ratus) motif batik khas Yogyakarta, mencakup Batik Klasik maupun batik modern. ${ }^{31}$

Menurut data tahun 2012 dari Dinas Perindustrian, Perdagangan, Koperasi, dan UKM Propinsi D.I. Yogyakarta, saat ini terdapat 48 unit UKM di kota Yogyakarta yang bergerak di bidang batik cap dan batik tulis. Sementara, di Kabupaten Bantul terdapat 334 unit UKM batik, 79 unit UKM batik tulis dan 6 unit UKM batik cap di Kabupaten Kulonprogo, 85 unit UKM batik di Kabupaten Gunungkidul, dan 10 unit UKM batik di Kabupaten Sleman.

\section{c. Sentra Batik di Pekalongan}

Pekalongan juga mendapat julukan kota batik, dan terkenal sebagai penghasil Batik Pesisir. Salah satu barometer pertumbuhan ekonomi Kota Pekalongan terletak pada sektor industri batik dan turunannya. $^{32}$ Sejak ratusan tahun lalu hingga sekarang, sebagian besar proses produksi Batik Pekalongan dikerjakan di rumah-rumah, sehingga menyatu erat dengan kehidupan masyarakat Pekalongan. Dikatakan oleh Semiarto Aji Purwanto, sejarah batik Pekalongan menunjukkan kemampuan mengadopsi berbagai pengaruh dan keluwesan untuk menerima pengaruh-pengaruh dari asing. Perjumpaan masyarakat Pekalongan dalam kegiatan perdagangan dengan berbagai bangsa seperti Cina, Belanda, Arab, India, Melayu dan Jepang pada zaman lampau telah mewarnai dinamika pada motif dan tata warna seni batik Pekalongan. Pengaruh-pengaruh dan interaksi dengan budaya dari bangsa lain tersebut melahirkan beberapa jenis motif batik baru yang khas dan menjadi identitas batik Pekalongan sebagai Batik Pesisir yang naturalis dengan elemenelemen kebudayaan asing. Sebagai contoh beberapa motif tersebut adalah motif Jlamprang yang diilhami dari Negeri India dan Arab, serta motif Encim dan Klenengan yang dipengaruhi oleh peranakan Cina. Motif Pagi-Sore dipengaruhi oleh Belanda, sementara motif Hokokai berkembang ketika masa pendudukan Jepang. ${ }^{33}$

Dari sisi warna, batik klasik Pekalongan mempunyai dua warna utama, yakni biru nila dan merah mengkudu. Dalam perkembangannya, sekitar awal tahun 2000 lahir jenis baru batik

${ }^{30}$ Balai Besar Kerajinan dan Batik Yogyakarta, http://www.batik.go.id.

${ }^{31}$ Op.cit., Katalog Batik Khas Yogyakarta, hlm. 2.

32 Pembangunan Daerah Bidang Koperasi dan Usaha Kecil Menengah, Website Pemerintah Kota Pekalongan, http://www.pekalongankota.go.id, diakses pada 17 Juli 2013.

33

Sejarah Singkat, Website Pemerintah Kota Pekalongan, http://www.pekalongankota.go.id, diakses pada 17 Juli 2013. 
pekalongan yang disebut-sebut sebagai batik kreasi baru atau batik abstrak. Dalam hal ini, para pembuat batik tersebut tidak lagi membuat batik dengan sebuah motif melalui cap, tetapi menumpuk berbagai motif dengan beberapa buah cap yang ada. Selain dengan menumpuk motif, para pembatik juga membatik tidak hanya pada kain polos, tetapi juga pada kain bermotif. ${ }^{34}$ Penjualan batik di Pekalongan dilakukan melalui showroom yang terletak di sekitar pemukiman atau kampung tempat pembuat batik tinggal, dan juga di sentra perdagangan batik di Pasar Grosir Setono, yang didirikan sejak pertengahan tahun $2000 .^{35}$ Di pasar yang terletak di Jln. Dr. Sutomo tersebut, dijual aneka produk batik dan tenun oleh sekitar 228 unit UKM. Selain itu, sentra batik lainnya di daerah Pekalongan meliputi: $^{36}$

(1) Sentra Batik Landungsari, dengan 19 unit UKM;

(2) Sentra Batik Kergon, dengan 31 unit UKM;

(3) Sentra Batik Kauman, dengan 31 unit UKM;

(4) Sentra Batik Krapyak Lor, dengan 12 unit UKM;

(5) Sentra Batik Degayu, dengan 18 unit UKM;

(6) Sentra Batik Pabean, dengan 18 unit UKM;

(7) Sentra Batik Kradenan, dengan 54 unit UKM;

(8) Sentra Batik Buaran, dengan 30 unit UKM;

(9) Sentra Batik Jenggot, dengan 32 unit UKM;

(10) Sentra Batik Banyurip Alit, dengan 25 unit UKM;

(11) Sentra Batik Banyurip Ageng, dengan 27 unit UKM;

(12) Sentra Batik Pasirsari, dengan 79 unit UKM;

(13) Sentra Batik Tegalrejo, dengan 29 unit UKM;

(14) Sentra Batik Pringlangu, dengan 44 unit UKM;

(15) Sentra Batik Tirto, dengan 37 unit UKM;

(16) Sentra Batik Medono, dengan 19 unit UKM.

Sementara, menurut data tahun 2012 dari Dinas Perindustrian, Perdahangan, Koperasi, dan UMKM Kota Pekalongan, terdapat 634 unit usaha batik di Pekalongan, 27 pengusaha diantaranya memiliki Merek terdaftar (data tahun 2010).

\section{Hasil Temuan Penelitian}

Dasar pertimbangan dari pembuatan UU Merek adalah untuk mewujudkan persaingan usaha yang sehat, serta memberikan layanan yang baik kepada masyarakat terkait dengan perlindungan Merek yakni melalui pendaftaran Hak Merek. Dalam hal ini, dasar pertimbangan tersebut dikaitkan dengan konteks tujuan UU Merek untuk:

\footnotetext{
${ }^{34}$ Op. Cit. Teruo, hlm. 10-11.

${ }^{35}$ Ibid. hlm. 19-22.

36 Sentra Industri, Dinas Perindustrian, Perdagangan, Koperasi, dan UMKM Kota Pekalongan, http://perindagkop.pekalongankota.go.id/, diakses pada 17 Juli 2013.
} 
1) Membuat pengusaha tidak mau melakukan peniruan atau pemalsuan atas Merek;

2) Membuat pengusaha berkeinginan dan secara sukarela mendaftarkan Mereknya ke Direktorat Jenderal Hak Kekayaan Intelektual ("DJHKI"); dan

3) Membuat pengusaha bekerjasama dalam memajukan usahanya dengan memanfaatkan perlindungan Merek Kolektif.

'Efektivitas' adalah suatu keadaan tercapainya tujuan yang dikehendaki. Dengan demikian, efektivitas pemanfaatan dan perlindungan hukum Merek akan dinilai berdasarkan pertimbangan apakah tujuan-tujuan UU Merek tersebut tercapai. Apabila tujuan-tujuan UU Merek pada kenyataannya tercapai, maka UU Merek tersebut efektif. Termasuk dalam tujuan UU Merek, sebagaimana disebutkan di atas, adalah keinginan para pengusaha untuk memanfaatkan dan mendaftarkan hak Mereknya. Oleh karena itu, dalam penelitian ini pertimbanganpertimbangan penilaian efektivitas tersebut mencakup:

1) Apakah mayoritas pengusaha UKM batik tidak mau melakukan peniruan atau pemalsuan Merek? Jika Ya, maka UU Merek efektif.

2) Apakah mayoritas pengusaha UKM batik merasa bahwa pemanfaatan Merek dapat berguna untuk memenangkan persaingan usaha? Jika Ya, maka pengusaha UKM batik merasa butuh untuk memiliki Merek.

3) Apakah mayoritas pengusaha UKM batik ingin mendaftarkan mereknya ke DJHKI karena keberadaan UU Merek? Jika Ya, maka UU Merek efektif.

4) Apakah mayoritas pengusaha UKM batik memandang bahwa produk batik dari kampungnya memiliki kekhasan sehingga mereka merasa perlu memberikan nama atau tanda khusus kepada produk tersebut agar semua orang dengan mudah mengenalinya? Jika Ya, maka para pengusaha UKM tersebut merasa butuh untuk memiliki merek kolektif.

5) Apakah mayoritas pengusaha UKM batik ingin mendaftarkan Merek Kolektifnya tersebut ke DJHKI karena keberadaan UU Merek? Jika Ya, maka UU Merek efektif.

Kunjungan awal ke sentra-sentra batik di Pekalongan, Solo, dan Yogyakarta menunjukkan fakta bahwa pengusaha UKM batik dapat dikategorikan menjadi beberapa kelompok, yakni:

1) Pengrajin batik sebagai pemilik workshop (rumah produksi);

2) Pengrajin batik yang sekaligus memiliki showroom;

3) Pemilik showroom batik;

4) Pengusaha konveksi batik, dan

5) Pengusaha konveksi batik yang sekaligus memiliki showroom. 
Perbedaan bidang tersebut sedikit banyak dapat mempengaruhi pemanfaatan Merek dan pentingnya perlindungan hukum Merek bagi usaha batik mereka. Wawancara awal dengan beberapa responden pengusaha batik mengindikasikan temuan sebagai berikut:

1) Bahwa pengrajin batik yang memiliki workshop tidak terlalu memanfaatkan Merek atau menganggap Mereknya penting, karena mereka biasanya membuat batik kosongan (tanpa label Merek) berdasarkan pesanan dari pihak lain;

2) Bahwa pengrajin batik yang sekaligus memiliki showroom memanfaatkan Merek untuk menandai dan membedakan produk mereka dari produk batik pengusaha lainnya;

3) Bahwa pemilik showroom batik yang bukan merupakan pengrajin, kurang menganggap Merek batik penting, karena mereka biasanya menjual berbagai macam batik dari berbagai pengrajin dengan Merek batik yang berbeda-beda;

4) Bahwa Merek bukan menjadi faktor yang utama untuk menarik konsumen membeli batik, melainkan berdasarkan pada kualitas dan motif batiknya;

5) Bahwa sebagian besar dari mereka tidak resah menghadapi persaingan dengan 'batik' impor dikarenakan mereka menganggap produk batik mereka telah memiliki pasar tersendiri dan konsumen mampu membedakan mana yang merupakan batik lokal dan mana yang 'batik' impor;

6) Bahwa beberapa alasan yang membuat mereka tidak tertarik untuk mendaftar Merek ke DJHKI adalah prosedurnya yang birokratis, dan Merek bukan menjadi faktor yang utama konsumen membeli produk batik.

Ada kecenderungan bahwa pemilik rumah produksi tidak memandang penting untuk memiliki Mereknya sendiri, dikarenakan sebagian besar pesanan yang mereka produksi berasal dari pembeli yang sudah memiliki Merek sendiri. Sedangkan, para pemilik toko atau showroom saja (tidak memiliki workshop batik) cenderung untuk membangun Merek tokonya, sementara Merek produk batiknya (label yang ditempelkan pada produk batik), tidak terlampau dianggap penting oleh mereka. Meskipun Merek bukan dianggap sebagai faktor yang utama untuk memenangkan persaingan dan menarik konsumen, dapat dikatakan bahwa rata-rata responden memahami bahwa mereka tidak seharusnya meniru Merek orang lain, dan pendaftaran atas Merek dapat lebih memberikan hak perlindungan hukum untuk penggunaan Merek tersebut. Selain daripada itu, rata-rata dari pengusaha juga menganggap bahwa produk batik mereka memiliki ciri khas yang membedakannya dengan produk batik lain, namun korelasinya dengan keinginan mereka untuk memanfaatkan dan mendaftarkan Merek masih perlu dikaji lebih lanjut. Temuan juga menunjukkan bahwa sebagian besar dari mereka ingin mendaftarkan hak Merek ke DJHKI meskipun keinginan tersebut 
terganjal beberapa hal, seperti: tidak mengetahui prosedur pendaftaran Merek, menunggu Mereknya terkenal, dan belum menjadi prioritas untuk mendukung usaha. Rata-rata responden mengetahui, bahwa ketika terdapat pihak lain yang meniru Merek mereka, kepemilikan hak atas Merek (terdaftar) dapat menguatkan posisi mereka untuk menuntut pihak yang meniru tersebut.

Sehubungan dengan Merek Kolektif, hasil temuan awal di Solo menunjukkan bahwa sentra batik Kampung Laweyan telah memproses pendaftaran atas Merek Kolektif 'Kampung Batik Laweyan.' Sementara, di Kabupaten Bantul propinsi D.I.Y. Yogyakarta pun masyarakat pengusaha batik berkeinginan untuk mendaftarkan Merek Kolektif atas batik Bantul. Rata-rata responden pengusaha UKM batik menganggap bahwa produk batik yang mereka jual atau produksi memiliki ciri khas kedaerahan masing-masing, yakni Solo, Yogyakarta, atau Pekalongan. Meskipun sebagian berpendapat bahwa perlindungan atas penggunaan Merek bersama bagi para pengusaha yang memiliki ciri khas batik kedaerahan yang sama tersebut dibutuhkan, sebagian menganggap bahwa perlindungan itu tidak diperlukan karena pada dasarnya setiap pengrajin batik menghasilkan produk yang memiliki ciri khas yang berbeda. Lalu mengenai Batikmark, rata-rata responden belum mengetahui mengenai program tersebut, baik tujuan, fungsinya dan prosedurnya, dan beberapa responden yang pernah mendengar belum memiliki persepsi yang seragam dan sesuai dengan apa yang menjadi tujuan dan fungsi dari Batikmark. Ada yang berpendapat bahwa Batikmark adalah sejenis standarisasi sebagaimana layaknya SNI, ada yang berpendapat bahwa Batikmark adalah untuk batik printing, sementara narasumber dari Balai Besar Kerajinan dan Batik menyebutkan bahwa Batikmark berfungsi sebagai tanda yang menunjukkan bahwa produk batik tersebut adalah batik tulis dan batik cap, atau kombinasi dari keduanya, yang berasal dari Indonesia.

\section{Penutup}

\section{Kesimpulan}

Berdasarkan hasil penelitian hingga saat ini, diketahui bahwa pemanfaatan Merek dan pentingnya perlindungan hukum Merek bagi pengusaha UKM batik bervariasi dan bergantung pula kepada jenis atau bidang usaha mereka, apakah: pemilik workshop atau rumah produksi batik, pemilik toko atau showroom batik, atau pemilik keduanya. Namun rata-rata responden menyatakan bahwa faktor utama untuk menarik konsumen adalah kualitas dan motif atau desain batik.

Produk yang diproduksi oleh rumah produksi batik, dapat dibedakan menjadi 4 (empat) macam, yakni:

(1) Batik tulis; 
(2) Batik cap;

(3) Tekstil printing bermotif batik ('Batik' printing);

(4) Kombinasi.

Rata-rata responden menganggap bahwa batik lokal memiliki keunggulan dibandingkan dengan 'batik' impor, dan bahwa produk batik tulis atau batik cap telah memiliki pasarnya sendiri karena kemampuan dan pilihan konsumen untuk membeli dan menggunakan batik lokal. Rata-rata responden juga tidak mau meniru Merek pengusaha lain, dan memahami bahwa pendaftaran atas hak Merek dapat memperkuat perlindungan atas penggunaan Merek miliknya. Tidak tampak adanya permasalahan dalam kaitannya dengan penggunaan Merek untuk produk batik. Oleh karena hampir tidak adanya kasus sengketa Merek di kalangan pengusaha UKM batik. Lalu, keinginan para pengusaha UKM batik untuk menggunakan dan mendaftar Merek Kolektif pun beragam, akan tetapi rata-rata responden menganggap bahwa produk batik yang mereka hasilkan memiliki ciri khas kedaerahan masing-masing.

Selanjutnya, program Batikmark dari Kementerian Perindustrian dan Perdagangan Republik Indonesia, belum terlaksana dengan baik karena kuantitas pengusaha UKM batik yang mendaftar Batikmark (dibandingkan dengan keseluruhan populasi pengusaha UKM batik) masih sedikit. Hal tersebut diantaranya disebabkan karena pola pikir dari rumah produksi batik yang memandang bahwa mereka belum membutuhkan sertifikasi Batikmark, dan tanpa sertifikasi tersebut pun mereka tetap dapat menjual batik dan meraih keuntungan. Selain itu, tampak belum adanya keseragaman persepsi mengenai hakekat dari Batikmark, dan bahkan sebagian belum mengetahui mengenai program tersebut. 


\section{Daftar Pustaka}

Elliot, Inger McCabe. Batik - Fabled Cloth of Java, English: Periplus Editions (HK) Ltd. 2004.

Hamzuri. Batik Klasik, Jakarta: Djambatan, 1989.

Katalog Batik Khas Yogyakarta. Kantor Wilayah Departemen Perindustrian Propinsi Daerah Istimewa Yogyakarta Yogyakarta: Proyek Pengembangan Industri Kecil dan Menengah (PIKM) Propinsi D.I. Yogyakarta, 1996.

Lin, Lee Chor. Batik - Creating an Identity, National Museum of Singapore, 2007.

Menteri Perindustrian Republik Indonesia. Peraturan Menteri Perindustrian Republik Indonesia Nomor: 74/M-IND/PER/9/2007 tentang Penggunaan Batikmark "batik Indonesia" pada Batik Buatan Indonesia.

Nomination for Inscription on the Representative List in 2009 (Reference No. 00170). Convention for the Safeguarding of the Intangible Cultural Heritage, Intergovernmental Committee for the Safeguarding of the Intangible Cultural Heritage, Fourth Session, Abu Dhabi, United Arab Emirates: UNESCO, 2009.

Republik Indonesia. Undang-Undang Nomor 19 Tahun 2012 tentang Hak Cipta, Lembaran Negara Republik Indonesia Nomor 85 Tahun 2002, Tambahan Lembaran Negara Nomor 4220.

Sardjono, Agus. "Titik Singgung Perlindungan HKI: Hak Cipta, Merek, dan Desain Industri”, Jurnal Hak Kekayaan Intelektual Vol. 1 No. 1, 2012.

Sari, Dyan Ratna. Ekses Pasal 10 UU No. 19 Tahun 2002 tentang Hak Cipta Terkait Pemanfaatan Motif Batik Surakarta. Skripsi, Fakultas Hukum Universitas Indonesia, 2013.

Sekimoto, Teruo, et.al. 2003. Handicrafts and Socio-Cultural Change: A Study of Batik Making in Cirebon and Pekalongan, Centre for Japanese Studies, University of Indonesia, 2003.

Widyawati, Naniek. Settlement of Batik Enterpreneurs in Surakarta Yogyakarta: Gadjah Mada University Press, 2004.

Wulandari, Ari. Batik Nusantara: Makna Filosofis, Cara Pembuatan, dan Industri Batik, Edisi 1, Yogyakarta: ANDI, 2011.

\section{Sumber Internet}

"Balai Besar Kerajinan dan Batik Yogyakarta", <http://www.batik.go.id>, diakses pada 18 Juli 2013.

"Batik Tulis", <http://www.kampoenglaweyan.com>, diakses pada 17 Juli 2013. 
"Batik dan Nilai Heritage", <http://www.batikyogyakarta.com/category/ sejarah/>, diakses pada 9 Juli 2013.

"Batikmark Sepi Peminat", Dinas Perindustrian, Perdagangan, Koperasi, dan UMKM Kota Pekalongan, <http://perindagkop.pekalongankota.go.id/>, diakses pada 18 Juli 2013.

"Busana Batik di Lingkungan Kraton", <http://www.kerajaannusantara.com/ $\mathrm{id} /$ surakarta-hadiningrat/busana-batik-keraton>, diakses pada 19 Juli 2013.

Geografi, <www.pekalongankota.go.id>, diakses pada 17 Juli 2013.

"Kampung Batik Kauman", <http://surakarta.go.id/konten/kampung-batikkauman>, diakses pada 18 Juli 2013.

"Pembangunan Daerah Bidang Koperasi dan Usaha Kecil Menengah", Website Pemerintah Kota Pekalongan, <http://www.pekalongankota.go.id>, diakses pada 17 Juli 2013.

"Sejarah - Kampoeng Laweyan", <http://www.kampoenglaweyan.com>, diakses pada 15 Juli 2013.

"Sejarah", <http://www.pemda-diy.go.id/>, diakses pada 17 Juli 2013.

"Sejarah Singkat", Website Pemerintah Kota Pekalongan, <http://www.pekalongankota.go.id>, diakses pada 17 Juli 2013.

"Selayang Pandang", <http://surakarta.go.id/konten/selayang-pandang>, diakses pada 18 Juli 2013.

"Sentra Industri", Dinas Perindustrian, Perdagangan, Koperasi, dan UMKM Kota Pekalongan, <http://perindagkop.pekalongankota.go.id/>, diakses pada 17 Juli 2013.

Steelyana, Evi, "Batik, A Beautiful Cultural Heritage that Preserve Culture and Support Economic Development in Indonesia", (Bina Nusantara University), diakses melalui <www.ssrn.com>, diakses pada 9 Juli 2013.

”Tentang Batik", <www.museumbatik.com>, diakses pada 9 Juli 2013. 